\title{
Dietary calcium intake and osteoporosis in postmenopausal women living in Sarajevo area
}

\author{
Amila Kapetanović ${ }^{1}$, Dijana Avdić² \\ ${ }^{1}$ Medical Rehabilitation Center Fojnica, Fojnica, Bosnia and Herzegovina. ${ }^{2}$ Clinic for orthopedics and traumatology, University \\ of Sarajevo Clinical Center, Bolnicka 25, Sarajevo, Bosnia and Herzegovina
}

\begin{abstract}
Introduction: Osteoporosis is a multifactorial polygenetic disease of which the genetic determinants are modulated by hormonal, environmental and nutritional factors. Identification of the risk factors for osteoporosis related to nutrition is important in the prevention and treatment of this disease, considering that these factors can be modified. The aim of this study was to examine influence of dietary calcium intake on bone mineral density in postmenopausal women who hadn't a deficit of estrogen in their menstrual history.

Methods: A total of 100 postmenopausal women living in Sarajevo area, aged 50-65 years, without estrogen deficiency in menstrual history were included in the study. Mineral bone density was measured at the lumbar spine and proximal femur by Dual-Energy X-ray Absorptiometry using Hologic QDR-4000 scanner. Examination and control group were formed based on mineral bone density values. The women in the examination group had osteoporosis. The women in the control group had osteopenia or normal mineral bone density. Estimates of daily dietary calcium intake were performed based on a Food Frequency Questionnaire.

Results: The average daily intake of dietary calcium among women who had osteoporosis was $967.32 \mathrm{mg}$, and in women who hadn't osteoporosis $1195.12 \mathrm{mg}$. The difference between two groups was statistically significant $(p<0.001)$. There was registered significant correlation between intake of dietary calcium and mineral bone density in examination $(p<0.01)$ and in control group $(p<0.01)$.

Conclusion: The results of this study have shown that adequate daily intake of dietary calcium in postmenopausal women aged 50-65 years living in Sarajevo area, which hadn't estrogen deficiency in their menstrual history (in the group of women without osteoporosis amounted to $1195.12 \mathrm{mg}$ ) has a positive impact on bone mineral density.

(c) 2012 All rights reserved
\end{abstract}

Keywords: dietary calcium intake, osteoporosis

\section{Introduction}

Osteoporosis is a systemic skeletal disease characterized by low bone mass and micro-architectural deterioration of bone tissue with a consequent increase in bone fragility and higher fracture risk (1). It is considered a multifactorial polygenetic disease of which the genetic determinants are modulated by hormonal, environmental and nutritional factors (2). Postmenopausal osteoporosis is related to the loss of gonadal function. The

\footnotetext{
* Corresponding author: Amila Kapetanović

Medical Rehabilitation Center Fojnica,

Fojnica, Bosnia and Herzegovina

E-mail: nermin1a@bih.net.ba

Tel: +387 30838 800; Fax: +387 30838848
}

Submitted: 10 July 2012 / Accepted: 20 August 2012. quantity and quality of the bone after menopause decreases rapidly resulting in an increased risk of fractures $(3,4)$. Estrogens are known to play an important role in regulating bone homeostasis and preventing postmenopausal bone loss (1). Research results regarding the effect of nutritional, environmental and lifestyle factors on bone mineral density and on the risk of bone fractures are not consistent, implying the need for further research which would contribute to providing relief for this problem. Calcium and vitamin D have received most of the attention directed to diet and bone health, but there are continuing questions about their benefits for bone health (5). People in some geographical areas with low calcium intakes (Japan) have a low incidence of osteoporotic frac- 


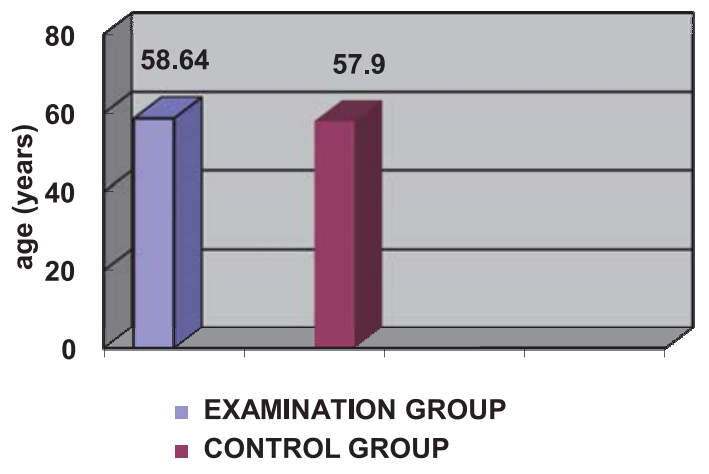

FGURE 1 The average age of women without estrogen deficiency in menstrual history. $t=0.746$, no statistically significant

tures, in contrast to some populations (Scandinavian countries) where average calcium intakes are high, have a high incidence of osteoporosis $(5,6)$. The recommendations for calcium intake vary widely among regional agencies. Variability in calcium intake recommendations can be explained partly by the discrepant results obtained in observational and interventional studies (7). Identification of the risk factors for osteoporosis that are related to nutrition is important in the prevention and treatment of this disease, considering that these are factors that can be modified. In addition to differences in the incidence of osteoporosis and osteoporotic fractures among racial groups, differences within the same race have also been determined as well as differences in conjunction with age and gender (8-13). Therefore, the importance of conducting research on osteoporosis within certain population groups has been confirmed. The aim of this study was to examine influence of dietary calcium intake on bone mineral density in postmenopausal women who hadn't a deficit of estrogen in their menstrual history.

\section{Methods}

A total of 100 postmenopausal women living in Sarajevo area (Sarajevo Canton), aged 50-65 years, without estrogen deficiency in menstrual history were included in the study. Examination and control group were formed based on mineral bone density values. The women in the examination group had osteoporosis. The women in the control group had osteopenia or normal mineral bone density. Mineral bone density was measured at the lumbar

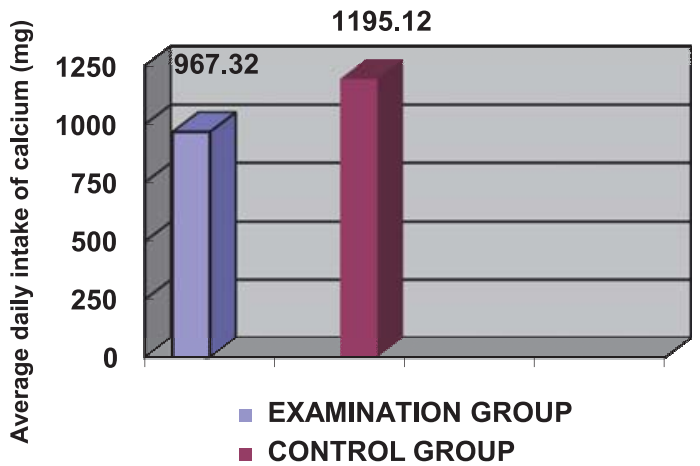

FGURE 2. Average daily intake of dietary calcium among women without estrogen deficiency in menstrual history. $p<$ 0.001

spine and proximal femur by Dual-Energy X-ray Absorptiometry using Hologic QDR-4000 scanner. Estimates of daily dietary calcium intake were performed based on a Food Frequency Questionnaire. Statistical processing and analysis of data was conducted. The difference in results was tested by using appropriate statistical tests of significance difference (Chi square test, t-test). The coefficient of linear correlation between dietary calcium intake and bone mineral density was calculated.

\section{Results}

The average age of women without estrogen deficiency in their menstrual history, in the examination group was 58.64 years, and in the control group was 57.9 years. There was no statistically significant differences between these two groups, $t=0.746$. Average daily intake of dietary calcium among women without estrogen deficiency in menstrual history was, in the examination group $967.32 \mathrm{mg}$, and in the control group 1195.12 $\mathrm{mg}$. The difference in the average daily intake of dietary calcium between the two groups was statistically significant, $\mathrm{p}<0.001$ The coefficient of linear correlation between $\mathrm{T}$ scores and daily intake of dietary calcium among women without estrogen deficiency in menstrual history in the examined group was statistically significant, $\mathrm{r}=0.677, \mathrm{p}<0.01$. The coefficient of linear correlation between $\mathrm{T}$ scores and daily intake of dietary calcium among women without estrogen deficiency in menstrual history in the control group was statistically significant, $\mathrm{r}=0.615, \mathrm{p}<0.01$. 
TABLE 1. The coefficient of linear correlation between $T$ score and daily intake of dietary calcium among women without estrogen deficiency in menstrual history

\begin{tabular}{lcc}
\hline Parameters & Examination group & Control group \\
\hline Coefficient of linear & $r=0.677$ & $r=0.615$ \\
correlation & $p<0.01$ & $p<0.01$ \\
\hline
\end{tabular}

\section{Discussion}

The female reproductive system plays a major role in regulating the acquisition and loss of bone by the skeleton from menarche through senescence (14). Estrogen deficiency (e.g., after menopause) increases the rate of remodeling and the volume of bone that is resorbed and decreases the volume of bone that is formed resulting in bone loss and structural decay after menopause (15). Kapetanović et al. found a significant association between menstrual factors (years between menarche and menopause, years since menopause) and bone mass loss in Bosnian postmenopausal women (16). Research results regarding the effect of calcium intake on bone mineral density and on the risk of bone fractures are not consistent. Park et al. found in their research that a high intake of dietary calcium, especially calcium from plant foods reduces the risk of osteoporosis and increase bone mineral density in Korean postmenopausal women (17). Napoli et al. studied the importance of sources of calcium intake on estrogen metabolism and bone mineral density in healthy postmenopausal women of white race. Intake of calcium form dietary sources was associated with higher bone mineral density than suplement calcium intake. The authors concluded that calcium from dietary sources may produce more favorable effects in bone health in postmenopausal women than will calcium from supplements (18). Ilic et al. have shown that there is significant correlation between bone mineral density in healthy Caucasian postmenopausal women and certain nutrients including calcium (19). Although the antifracture effect of calcium alone is questionable, several observations justify the recommendation to avoid calcium deficiency in this age (20). Results of the Feskanich et al. study showed that total calcium intake in postmenopausal women (through diet and supplementation) was not associated with risk of hip fracture and that consumption of milk is not associated with lower risk of hip fracture (compared was intake of $1200 \mathrm{mg}$ / day or more with calcium intake below $600 \mathrm{mg} /$ day), and that consumption of milk is not associated with lower risk of hip fracture. Conclusion of their study is that neither milk nor a high-calcium diet appears to reduce risk of hip fracture in postmenopausal women (21). Fardellone et al. have not found a difference in the average daily calcium intake between women with and without a diagnosis of osteoporosis or with and without fractures. The study involved postmenopausal women aged 45 years and over (22). The results of this study have shown that adequate daily intake of dietary calcium in order to preserve and promote bone health in postmenopausal women, aged 50-65 years, living in the Sarajevo Canton, which hadn't estrogen deficiency in their menstrual history, was 1195.12 mg (the group of women without osteoporosis). Average daily intake of dietary calcium in postmenopausal women which hadn't estrogen deficiency in their menstrual history in the group of women with osteoporosis was $967.32 \mathrm{mg}$.

\section{Conclusion}

The results of this study have shown that adequate daily intake of dietary calcium in postmenopausal women aged 50-65 years living in Sarajevo area, which hadn't estrogen deficiency in their menstrual history (in the group of women without osteoporosis amounted to $1195.12 \mathrm{mg}$ ) has a positive impact on bone mineral density.

\section{Conflict of interest}

Authors declare no conflict of interest 


\section{References}

(1) World Health organization. Assessment of fracture risk and its application to screening for postmenopausal osteoporosis. Report of a WHO Study Group. WHO Technical Report Series 843; 1994.

(2) Gennari L, Merlotti D, De Paola V, Calabro A, Becherini L, Martini G, et al. Estrogen receptor gene polymorphisms and the genetics of osteoporosis: a HuGE review. Am J Epidemiol. 2005;161(4):307-20.

(3) Delaney MF. Strategies for prevention and treatment of osteoporosis during early postmenopause. Am J Obstet Gynecol, 2006;194(2 Suppl):S12-23

(4) McClung MR. The menopause and HRT. Prevention and management of osteoporosis. Best Pract Res Clin Endocrinol Metab, 2003;17(1):5371

(5) Gueldner SH, Grabo TN, Newman ED, Cooper DR. Osteoporosis Clinical Guidelines for Prevention, Diagnosis and Management. Springer Publishing Company, 2008.

(6) FAO / WHO. Human vitamin and mineral Requirments. Report of a joint FAO/WHO expert consultation 2002.

(7) Roux C. The living skeleton. Wolters Kluwer Health France, 2007.

(8) Barrett-Connor E, Siris ES, Wehren LE, Miller PD, Abbott TA, Berger $\mathrm{ML}$, et al. Osteoporosis and fracture risk in women of different ethnic groups. J Bone Miner Res.
2005;20(2):185-94.

(9) Kanis JA, Johnell O, De Leat C, Jonsson B, Oden A, Ogelsby AK. International variations in hip fracture probabilities: implications for risk assessment. J Bone Miner Res. 2002; 17(7):1237-44.

(10) Sambrook P, Kelly P, Eisman J. Bone mass and ageing. Baillieres Clin Rheumatol. 1993;7(3):445-57.

(11) Nelson HD, Morris CD, Kraemer $\mathrm{DF}$, et al. Osteoporosis in postmenopausal women: diagnosis and monitoring. Evidence Report/ Technology Assessment No.28. AHRQ Publication No. 01-E032. Rockville, MD: Agency for Healthcare Research and Quality. January 2001.

(12) Looker AC, Orwoll ES, Johnston CC, Jr., Lindsay RL, Wahner HW, Dunn WL, et al. Prevalence of low femoral bone density in older U.S. adults from NHANES III. J Bone Miner Res. 1997;12(11):1761-8.

(13) Looker AC, Melton LJ 3rd, Harris TB, Borrud LG, Shepherd JA. Prevalence and trends in low femur bone density among older US adults: NHANES 2005-2006 compared with NHANES III. J Bone Miner Res. 2010;25(1):64-71.

(14) Clarke BL, Khosla S. Female reproductive system and bone. Arch Biochem Biophys. 2010;503(1):118-28.

(15) Seeman E, Delmas PD. Bone quality--the material and structural basis of bone strength and fragility. $\mathrm{N}$ Engl J Med. 2006;354(21):2250-61.
(16) Kapetanović A, Avdić D, Marković K. Uticaj menstrualnih faktora na gubitak koštane mase kod bosanskih žena u postmenopauzi. HealthMed, 2007; 1(2): 2-9

(17) Park HM, Heo J, Park Y. Calcium from plant sources is beneficial to lowering the risk of osteoporosis in postmenopausal Korean women. Nutr Res. 2011;31(1):27-32.

(18) Napoli N, Thompson J, Civitelli R, Armamento-Villareal RC. Effects of dietary calcium compared with calcium supplements on estrogen metabolism and bone mineral density. Am J Clin Nutr. 2007;85(5):1428-33.

(19) Ilich JZ, Brownbill RA, Tamborini L. Bone and nutrition in elderly women: protein, energy, and calcium as main determinants of bone mineral density. Eur J Clin Nutr. 2003;57(4):554-65.

(20) Burckhardt P. Calcium supplementation in the menopause-unnecessary, advisable, or necessary? Ther Umsch. 2007;64(5):259-63.

(21) Feskanich D, Willett WC, Colditz GA. Calcium, vitamin D, milk consumption, and hip fractures: a prospective study among postmenopausal women. Am J Clin Nutr. 2003;77(2):504-11.

(22) Fardellone P, Cotté FE, Roux C, Lespessailles E, Mercier F, Gaudin AF. Calcium intake and the risk of osteoporosis and fractures in French women. Joint Bone Spine. 2010;77(2):154-8. 